\title{
EFFECTS OF PERCEIVED ORIGIN ON ANTI-MIGRANT SENTIMENTS AND ACTS OF SOCIALLY INDUCED HATRED IN BULGARIA
}

\begin{abstract}
The paper studies the effects of perceived immigrants' origin on anti-immigrant sentiments in the Bulgarian society by focusing on social distance and some aspects of socially induced hatred towards immigrants. Spread and approval of hate speech and hate violence against immigrants and variations associated to the perceived different background and origin are analyzed. With respect to social distancing, two clusters are differentiated - "distant" and "close" on basis of origin and the differences between them are not only in the degree of acceptance, but also in the ranking of preferred roles. With respect to act of socially induced hatred results are more ambiguous. Origin has a substantial role on the spread of hate speech, but this is not the case with the spread or (perceived) involvement of different groups in violence. Inclination to intervene and stop violence differs according to the origin of victims and perpetrators and further studies are needed to identify determinants.
\end{abstract}

Keywords: social distance, anti-immigrant sentiments, hate speech, hate violence

\section{Introduction}

Two main lines of theorizing and analysis can be distinguished with respect to sources of anti-immigrant sentiments, according to which they are to be attributed to economical (O’Rourke \& Sinnott, 2006; Dustmann \& Preston, 2007) or cultural (Davidov \& Meuleman, 2012; Billiet \& De Witte, 1995; Ceobanu \& Escandell, 2008) confrontation. Most of the papers arguing that anti-immigrant sentiments are due to cultural confrontation assume, implicitly or explicitly, that symbolic concerns and anticipated sociotropic effects (Hainmueller \& Hopkins, 2014) are related to perceptions of the otherness of the immigrants in terms of values, religion, culture, ethnicity, race, etc. (Gorodzeisky \& Semyonov, 2015; Gorodzeisky, 2013; Scheepers, Gijsberts, Coenders, 2002). There is however, little research

\footnotetext{
1 lspasova@bas.bg
} 
on the way specific cleavages of difference and perceived forms of otherness affect anti-immigrant sentiments and in particular on the effects of perceptions of origin of different groups on the concrete sentiments towards them (some notable recent exceptions being: Blinder \& Markaki, 2018; Heath \& Richards, 2019). Studies on the effects of perceived origin on anti-immigrant hate speech, hate crimes and hate motivated violence are even scarce.

The paper tries to fill this gap by analyzing the effects of the perceived immigrant's origin on anti-immigrant sentiments in Bulgaria measurable through social distancing towards different immigrant groups and through manifestations of socially induced hatred. The paper contributes as well with analysis of the spread and acceptance of anti-immigrant hate speech and hate motivated violence.

The study is part of a larger research, funded by the Bulgarian Science Fund, and draws on data from a set of representative surveys on attitudes of Bulgarians towards immigrants and refugees at the peak and after the wave of intensified migration.

The paper is structured as follows: the first part introduces the main theoretical notions and concepts; after that the second present the methodology of the empirical study; the third part presents the data and results of the research; finally, the last part concludes with an overview of the most important findings and some notes on possible future research.

\section{Theoretical framework}

Studies focused on sources and consequences of anti-immigrant sentiments are abundant, however rarely comprehensive (Ceobanu \& Escandell, 2010; Gorodzeisky, 2013). There are two main lines of theorizing and analysis, which only seldom and only recently overlap (Hainmueller \& Hopkins, 2014; Gorodzeisky, 2013). The first line of inquiry is grounded in political economy and is concerned with economic self-interest or collective economic interest like labor market competition and fiscal burden (O'Rourke \& Sinnott, 2006; Dustmann \& Preston, 2007). The second - sociopsychological - suggests sources of anti-immigrant attitudes are to be found in the perceptions of a sociotropic effect (Hainmueller \& Hopkins, 2014) on the host country and society. Studies in this paradigm are much more heterogeneous and study a variety of factors such as identities and values (Davidov \& Meuleman, 2012; Billiet \& De Witte 1995), nationalism (Ceobanu \& Escandell, 2008), perceived threat (Scheepers et al., 2002). Despite abundant research, there is little proof that anti-immigrant attitudes are based on the real or anticipated effects on the personal economic situations. More consistently, recent research shows that attitudes towards immigrants are "mostly driven by symbolic concerns about the nation as a whole" (Hainmueller \& Hopkins, 2014, p. 227) or by "concerns over the conditions or characteristics of the immigrant population” (Markaki, Longhi, 2013, p. 332).

Dustmann and Preston (2007) present evidence that racial or cultural prejudice is an important component to attitudes towards immigration when it comes to immigration from countries with ethnically different populations.

Similarly, according to Gorodzeisky and Semyonov (2009) anti-immigrant sentiments, and specifically exclusionary attitudes, can be formed on grounds of national origin or national membership and on grounds of race and ethnicity. The first type is directed "indiscriminately' at all non-nationals (or 'foreigners') regardless of their race or ethnicity" 
and the second is "directed 'selectively' only at non-European ethnic and racial minorities" (Gorodzeisky \& Semyonov, 2009, p. 416). The two authors argue that Europeans are more willing to endorse exclusion of immigrants of non-European origin than immigrants of European origin. This thesis is further developed by Gorodzeisky and Semyonov (2015), according to which ethnic and racial prejudices toward non-European/non-White minorities and competitive threat (both at individual and country levels) are two independent sources of attitudes toward all immigrants, i.e. prejudiced attitude serves both as surplus to perception of threat and as independent factor for anti-immigrant sentiments. What is more, according to them, "racial prejudice toward non-White/non-Europeans should be seen as an independent (and additive) source of negative attitudes toward immigrants in general" (Gorodzeisky \& Semyonov, 2015, p. 20).

As suggested by Gorodzeisky in another line of research (Gorodzeisky, 2011) not only ethnical or racial prejudice form anti-immigrant sentiments, but also perceptions of the economic conditions in the country of origin. Using data from the first round of the ESS and cross-referencing attitudes towards immigrants from poorer versus richer countries in Europe, she identifies four categories of attitudes: pro-admissionists, total exclusionists, poor country exclusionists, rich country exclusionists). According to Gorodzeisky (2011), exclusionary views directed exclusively at foreigners from 'poorer countries in Europe' or at foreigners 'from richer countries in Europe' are quite substantial, although the majority of people do not distinguish. Similarly, Blinder \& Markaki (2018) found evidence that both economic conditions in the country of origin and origin from within or out of EU and can play a role in attitude towards immigrants. In their conclusions the two authors go further than Gorodzeisky, arguing that the economic conditions in the country of origin are much more important for anti-immigrant sentiments than European or non-European origin.

In a recent article Heath and Richards (2019) present evidence that there is considerable over-time stability in the attitudes towards immigrants and sentiments towards different groups of immigrants. According to them, immigrants "of the same racial or ethnic group as the majority are preferred to those from a different ethnic group or those from poorer countries in Europe, who in turn are slightly preferred to those from poorer countries outside Europe" (Heath \& Richards, 2019, p. 17). The two authors as well conclude that there are more negative attitudes towards Muslim migrants and the least desired are migrants with Roma origin.

With regards to anti-immigrant prejudice, earlier works of Pettigrew (Pettigrew, 1998) argue that waves of intensified migration led to increased prejudice, direct and indirect discrimination, political opposition, and extensive violence to immigrants and immigrant minorities.

Building on the previous findings on hate crimes and hate speech (Spasova, 2019) the current study assumes that the main factor for aggression and violence in intergroup relations and in particular the ones targeted at immigrants, are precisely prejudices - distorted categorizations of social groups. Prejudice is understood as a "negative assessment of a social group or a negative assessment of a particular individual that is based on his / her group affiliation" (Crandall \& Eshleman, 2003: 414), which is spread through culture and internalized through experience (e.g. Dunham, Chen, Banaji, 2013).

Acts of hatred - hate motivated violence, hate crimes and hate speech, are deviant acts, motivated by prejudice, which serve to further confirm the prejudices of the group 
with which the perpetrators identify. Following Allport's classical understanding, hate here refers to a complex mental phenomenon representing a "permanent organization of aggressive impulses to a person or group of people" that is a difficult structure in the mental and emotional life of the individual (Allport, 1979: 363). In this sense, hatred is stable over time - sentiment, not emotion or affect, and yet more or less passive, but driving impulse associated with the behaviour. Hatred is what acts as a "motivating force for violence" (Kressel, 2002).

It is important to point that hatred does not have to be the main motive for a criminal or violent act in order for that act to be classified as manifestation of socially induced hatred. As other researchers point out (McDevitt, Levin, Bennett, 2002); Perry, 2009; Walters, 2011), even when hatred is not the main motive for a particular criminal act, it can still play a significant role in overall motivation, for example in choosing a victim. Similar is the difference described by Herek, Berrill and Berrill (1992) between "expressive" and "evaluative" hate-motivated attacks: expressive violence aims to destroy or harm the victim because of his / her identity and belonging to a certain group, and evaluative violence is directed to the specific victim due to its perception as an obvious goal.

Although hate speech is not necessarily violent in itself, a number of studies have unambiguously linked the use of hate speech to the triggering of violence (e.g. Yanagizawa-Drott, 2014; Benesh, 2012). The term includes incitement to violence, radicalism and genocide, which constitutes a crime according to the law, as well as insults and qualifications based on identification and belonging to a certain group, which in itself is not criminalized. The study uses a definition of hate speech, according to which these are "forms of expression that disseminate, incite, facilitate or justify harm (specifically, discrimination, hostility or violence) based on the victim's social or demographic affiliation to a group" (UNESCO, 2015).

Essential for understanding the effects of hate speech are studies of the so-called "dangerous speech" (Benesh, 2012) and "language of fear" (Buyse, 2014), which emphasize the frequency of use and the speakers of hate - whether they are officials, journalists or ordinary citizens. According to research on media content preceding acts of genocide, the use of hate speech by officials or in the official media is key to objectifying hatred and radicalism into violence (Benesh, 2012; Leader Maynard \& Benesch, 2016).

\section{Research methodology}

Empirical data are collected via a series of PAPI (Pen-and-paper assisted personal interviews) studies with a structured questionnaire. The information mainly used in the analysis is from the last survey which was conducted in the period September-October 2019 , as already mentioned - after the depletion of the massive inflow of migrants from third countries. For comparison on several occasions in the analysis data from the wave conducted in November-December 2017 is used. Taking into consideration the importance of spatial and psychological proximity and distance (Liberman \& Chaiken, 1996), both studies are designed as a two-stage nested sample and use a sample model that is nationally representative for the adult population. The samples are random stratified with a volume of 840 individuals in 2019 and 800 individuals in 2017. The stratification is according to NUTS 2 by the size of the settlement. The settlements are grouped in six groups and 
the sample excludes settlements with less than one hundred people (which is $1 \%$ of the general population). The nests are 80 with ten interviews per nest. The source of information for the sampling plans in both surveys is the 2011 census - the breakdown by age groups for each settlement. The stochastic error at $50 \%$ is estimated to be $\pm 3,5 \%$. Data are weighted by sex and age.

To study anti-immigrant sentiments, the study employs an adapted variant of the Bogardus social scale (Bogardus, 1959). Inspired by Simmel's ideas on geometry of social life (Wark \& Galliher, 2007), Bogardus devised a scale intended to measure prejudice and to "reduce rationalizing....as much as possible" (1959, p. 30). The original scale is elegantly simple and consists of seven roles with an increasing level of social proximity and closer contact. Respondents are asked to select the closest degree of intimacy that they find suitable for representatives of certain ethnic groups. In the current study four of the degrees of proximity of the Bogardus social distance scale are used - immediate neighbour, direct supervisor or employer, married to a close relative, close friend. The social distance scale is modified using a Likert-type scale with four response categories for each separate role, thus turning the cumulative Bogardus scale into a set of separate questions with unidimensional scale.

Manifestations of socially induced hatred - hate speech and hate violence - are studied with questions for experience, for opinion and with a battery of original projective questions, specially developed for the research. The projective questions are designed to suggest responses describing the alleged behaviour of the respondents in various situations of immigrants/foreigners related violence, defined solely by the origin of the victims and attackers.

\section{Results}

With respect to social distance and acceptance, despite small variations, immigrants with different origin can be grouped into two clusters with similar in-group results and significant difference from each. The first cluster includes immigrants that are accepted more and easily and thus can be labeled "close immigrants". Those are immigrants from ethnic Bulgarian descent born and raised outside of the country and other Europeans from countries in or out of the EU. The second cluster includes immigrants that are accepted less, especially with the increase of social proximity, and can be labeled "distant immigrants". This cluster includes immigrants from Africa, the Middle East (Syria, Iraq, Afghanistan, etc.) and China (Figure 1).

Approximately one third of Bulgarians would feel completely comfortable if their immediate neighbour is someone from the "close immigrants" - a European from outside the EU (34\%) or ethnic Bulgarian from another country (31\%), and one third (32\% and $33 \%$ respectively), would feel some degree of uncomfortably. For the immigrants from Africa and the Middle East proximately two thirds say they would feel uncomfortable (31\% - "completely uncomfortable" and 31\% "somewhat uncomfortable" for a person from the Middle East and 34\% "completely uncomfortable" and 29\% "somewhat uncomfortable" for a person from Africa). Only $9 \%$ and $8 \%$ of Bulgarians, respectively, would feel completely comfortable if their neighbour is someone from Africa or the Middle East.

Regarding direct supervisor or employer, $25 \%$ of Bulgarians state they would be completely comfortable if a European from outside EU or an ethnic Bulgarian from another 
country is on that position and $36 \%$ - that they would feel uncomfortable ( $16 \%$ - "completely uncomfortable" and 20\% "somewhat uncomfortable" for an ethnic Bulgarian and $15 \%$ "completely uncomfortable" and 21\% "somewhat uncomfortable" for European from outside EU) if this is the case. As in other positions, the acceptance of the other three groups is significantly lower. Least comfortable Bulgarians would feel if their direct supervisor is a person from the Middle East as this hypothetical situation would be completely comfortable only for $10 \%$, somewhat uncomfortable for $24 \%$ and completely uncomfortable for $31 \%$.

The distribution of the social distance preferences towards different groups of immigrants for the position of a close relative by marriage displays even more pronounced differences between the two clusters and almost identical result for the groups in each of them. $29 \%$ of Bulgarians would feel completely comfortable if they become relatives by marriage with someone from the group of the close immigrants, whereas only $7 \%$ (or $6 \%$ for Africa) would feel this way in the same situation but with a person from the group of distant migrants. Albeit with a minimal difference, the people from Africa are least desired $20 \%$ have indicated that for them origin doesn't matter, $6 \%$ would feel completely comfortable, $23 \%$ - somewhat uncomfortable and 50\% - completely uncomfortable.

It is important to note that for all levels of proximity there are differences with regard to the stated irrelevance of the origin. For example, on the kinship by marriage where the discrepancy is biggest, $31 \%$ of the respondents have stated this for immigrants from a European descent, 29\% - for an ethnic Bulgarian from another country, 22\% - for immigrants coming from the Middle East and 20\% - for immigrants from Africa. Such a discrepancy should not exist, if, as the answer suggests, in reality the origin of the relatives by marriage is irrelevant. A possible explanation would be the existence of a certain degree of social desirability in these responses, which, however, does not work well enough for the distant immigrants.

A social distance index that reflects the level of comfort was created to enable a comparison that includes both the tested migrant groups and the tested social roles. The index was created by assigning weight to the different levels of comfortability and takes values between 0 and 100 where 0 means completely uncomfortable for everyone, and 100 - completely comfortable or origin is irrelevant for everyone. The index reveals several rather interesting results. It is somewhat surprising to note that for the above discussed positions ethnic Bulgarians from another country are less desirable than other Europeans. As it will be seen in the analysis below however this is not the case for the position of close friend. Further, for the group of closer immigrants, the most accepted role is the one of an immediate neighbour, while for the group of distant immigrants the most accepted role is that of direct employer. This difference is another important cleavage in the clustering of the groups of immigrants as close and distant.

For the next tested role - the one of a close friend, most accepted by Bulgarians are the ethnic Bulgarians from another country with $78 \%$ of the respondents willing to accept them. Europeans from a third country come to a second place with $71 \%$ willing to accept them. Immigrants from the Middle East, Africa and China are, as expected, considerably less accepted. A person from China would be accepted as a close friend by $44 \%$, a person from the Middle East - by $38 \%$, a person from Africa - by $35 \%$. 
Though the social distance for this role is quite high, especially for the cluster of distant immigrants, a comparison with data from 2017 shows a probable increase in the level of acceptance. Methodological considerations should be kept in mind, concerned with the fact that in 2017 acceptance was not tested for different groups but for all immigrants at large. Data show that in 2017 - much closer to the peak of the migrant inflow, only $23 \%$ would accept an immigrant, regardless of origin, as their close friend. In 2019 acceptance is several times higher for the close immigrants and much higher even for the distant immigrants. A possible explanation for these results is the reduced sensitivity towards the topic due the decrease in the migrant inflow that, one might argue, is linked to reduced perception of potential threat and the lessening of social panics.

Furthermore, the results on the assessment of hate speech prevalence allow some very interesting observations.

According to the respondents, statements containing insulting qualifications (the respondents are given the freedom to decide for themselves what qualifies as an insulting statement) are most commonly against immigrants from Africa and the Middle East. 21\% say they have heard such statements often, $40 \%$ - rather rarely and 39\% - never. Next in prevalence are such statements against immigrants from China, followed by statements against immigrants of Bulgarian origin from other countries and statements against citizens of other European countries. Most rarely respondents have heard insulting statements against immigrants from third European countries - 5\% have heard such statements often, $30 \%$ - rather rarely and $65 \%$ - never.

Quite similar, but with much lower values, is the distribution of the prevalence of the more serious type of hate speech - those containing threats and aggression (again, respondents are given the freedom to decide for themselves what qualifies as threats and verbal aggression). According to the results, such statements against immigrants from Africa and the Middle East are again the most common, but here $9 \%$ have often heard such statements, $27 \%$ have rarely heard them and never $64 \%$. As insulting statements, statements containing threats and aggression against immigrants from third European countries are most rare $3 \%$ have heard such statements often, $19 \%$ - rather rarely and $78 \%$ - never.

To enable a comparison simultaneously of both types of hate statements for all immigrant groups an index of hate speech was created by assigning weight to the three variables in the scale for distribution assessment. The index takes values between 0 and 100 where 0 means that none ever heard such statements and 100 - that everyone estimates such statements as rather common (Figure 2).

As visible from the index, the difference between the distribution of statements containing offensive qualifications and those containing threats and aggression is in the level rather than in the proportions. This applies both to the ratios within each group of immigrants and to the ratios between the different groups. The similar distributions suggest a hypothesis that there is a relation between the two groups of statements, which hypothesis is supported by the correlation analysis. The results show that there is a statistically significant association between the respondents' assessments of the degree of prevalence of the two types of statements, with the values being highest when both statements are related to the same group of immigrants. For example, for immigrants from third European countries, who according to the respondents are subjected to both statements containing insults and 
statements containing threats and aggression to the smallest degree, the correlation values are: Appr. Significance $=0.000$; Cramer's $V=0.541$. For the immigrants from Africa and the Middle East, most commonly subjected to both types of hate statements, these values are: Appr. Significance $=0.000$; Cramer's V $=0.487$.

With regard to dangerous speech - anti-immigrant and anti-refugee hate speech by public figures - according to the data of the current survey, $11 \%$ of Bulgarians accept the use of offensive phrases by politicians, $10 \%$ - by journalists, $22 \%$ consider acceptable the use of hate speech by ordinary people, and 15\% - by themselves (Figure 3). In terms of proportion, this distribution corresponds to the results of 2017, although there has since been a significant decline in the overall level of acceptance. To an identical question in $2017,19.2 \%$ of respondents indicated that they accept the use of hate speech and insulting phrases by politicians, $20.1 \%$ - by journalists, $44.1 \%$ - by ordinary people, and $35.6 \%$ by themselves.

Although the sample does not allow observations and conclusions on the level of hate crime victimization or hate crime offending of immigrants, the results connected to eyewitness experience of aggressive behaviour and acts of violence provide some information. A relatively small proportion of the respondents report having witnessed aggressive behaviour by or against foreigners and immigrants, with aggressive acts perpetrated by immigrants generally being less than those against them. $7 \%$ have witnessed aggressive behaviour by citizens of other EU countries, immigrants from third European countries and immigrants from the Middle East and Africa and 4\% - by immigrants from Asia. Instances of aggressive behaviour targeted at citizens of other EU countries have been seen by $12 \%$ of the respondents. $8 \%$ report having seen aggression targeted at immigrants from the Middle East and Africa, 7\% - at immigrants from third European countries and 5\% at immigrants from Asia.

Results from the projective questions, show that acceptance and approval of anti-immigrant violence is much higher than the reported incidents of violence. In an imaginary situation of violence against immigrants, and it should be emphasized that the victim is defined only on this basis, $80 \%$ of respondents agree that violence is never justified but $20 \%$ are of the option that "immigrants are guilty - they had to stay where they are from". The data unequivocally show a high degree of normalization of acts of physical violence and hate crimes, moreover, that the results of 2017 are exactly the same, i.e. this attitude is stable over time.

The set of projective questions on the presumptive reactions of the respondents in situations of violence also show a strong influence of prejudice against members of outgroups. Although a situation specifically with immigrants has been not tested, results are important for understanding attitudes towards different groups of immigrants. In the general case - a situation of violence that is not defined in any way, 13\% of Bulgarians assess the likelihood of intervening to stop the violence as very high, $32 \%$ are likely to intervene to some extent, $29 \%$ - to a small extent and $27 \%$ would not intervene at all. In situations where the victims are of Bulgarian origin and the perpetrators belong to various outgroups, the willingness and likelihood of intervention to stop the violence is close (within the margin of error) to that in the general situation. Although with a small difference, it is interesting to note that in the case of attackers from another ethnicity and in the case of attackers from another race the percentage of people who think they would most likely 
Lyuba D. Spasova, Effects of perceived origin on anti-migrant sentiments and acts of socially...

react is higher. In case of attackers from another ethnicity $14 \%$ assess the likelihood of interfering as very high and $28 \%$ - as nonexistent, and in case of attacker from another race $15 \%$ assess the likelihood of interfering as very high and $27 \%$ - as nonexistent. In situations where the positions are reversed and Bulgarians are the perpetrators, and the victims are members of out-groups, the willingness to intervene is lower than in the general case. For example, in a situation in which the victims are of another race or another ethnicity, $8 \%$ are likely to intervene to a very large extent, and $31 \%$ would not react at all. With victims of another religion those percentages are $8 \%$ and $32 \%$ respectively and with victims of foreign origin $-7 \%$ and $32 \%$.

The differences in the attitude and likelihood of reactions in the different situations are clearly seen from the index chart created by assigning weight to the various degrees of likelihood (Figure 4. The index takes values between 0 and 100 where 0 means that no one will react and intervene and 100 - that everyone estimates the likelihood of intervening as very high.

\section{Discussion and conclusion}

The study shows that perceived origin has a significant effect on anti-immigrant sentiments in Bulgaria both is terms of social distancing towards different immigrant groups and in terms of manifestations and acceptance of acts of socially induced hatred.

With respect to social distancing and acceptance of immigrant, two clusters are differentiated - "distant" and "close", as the distinction between the two is not only in the levels of acceptance, but also in the differing ranking of roles according to acceptance preferences. The differences in the ranking of roles indicate that the roles are not necessarily monovalent in terms of social distance and is an important indicator for attribution of immigrant groups to the two clusters.

Although in general it seems that immigrants in the "distant" cluster as a rule originate from countries that are more distant in terms of geography or culture and those in the "close" come from countries that are closer, social distance is not direct reflection of geographical or cultural distance. For example, the results evidence that people from China are generally more preferred than people from the Middle East for almost all social roles, although the latter are closer both culturally and geographically. Furthermore, contrary to expectations, ethnic Bulgarians living in another country, who are supposedly closest in terms of culture, are not the most preferred group for three out of four tested positions. Further research is needed to deepen the understanding of these results and establish possible explanations.

With regard to spread and acceptance of acts motivated by socially induced hatred, perceived origin of immigrants has substantial effects, although results are much more ambiguous. Spread of hate speech vary for immigrants of different origin and groups cannot be clustered. Spread and acceptance of hate speech do not exhibit dangerous trends, as acceptance of statements containing aggression and threats, is lower than acceptance of statements containing insults, and dangerous speech is less accepted hate speech used by ordinary people.

A relatively small proportion of respondents report having witnessed acts of violence in which immigrants or foreigners are involved - either as victims or perpetrators. 
Nevertheless, results show that, on the whole, immigrants and foreigners are (considered) more often the victims of violence than the perpetrators. Again, there is no ground for clustering different groups with respect to involvement in violence.

There are differences in the inclination to intervene and stop violence dependent on the roles and origin of victims and perpetrators. However, the association of inclination to react in different situations is very strong with the principal inclination and further study is needed to identify strongest determinants.

Comparisons with data from previous years reveal some contradictory data. While there is a marked decline in anti-immigrant sentiments in terms of social distance and approval of anti-immigrant hate speech, the approval of anti-immigrant acts of violence has remained stable over time. Further research in the next years is needed to study whether those results are a random variation, a temporary phenomenon or a trend and in fact - a shift in anti-immigrant sentiments. 
Љуба Д. Спасова ${ }^{1}$

Бугарска академија наука,

Институт за филозофију и социологију

Софија (Бугарска)

\title{
УТИЦАЈИ ПЕРЦИПИРАНОГ ПОРЕКЛА НА АНТИМИГРАНТСКА ОСЕЋАЮА И ЧИНОВЕ ДРУШТВЕНО ИЗАЗВАНЕ МРЖЬЕ У БУГАРСКОЈ
}

\author{
(Превоg In Extenso)
}

Сажетак: Овај рад проучава утицаје перципираног порекла миграната на антимигрантска осећања у бугарском друштву, усредсрећујући се на социјалну дистанцу и поједине аспекте друштвено изазване мржње према мигрантима. Анализирају се ширење и одобравање говора мржње и насиља из мржње према мигрантима, као и варијације повезане са перципираним различитим околностима и пореклом. Када је реч о социјалној дистанци, издвајају се два кластера - „далеки” и „блиски”, на основу порекла, а разлике међу њима нису само у степену прихватања, већ и у рангирању жељених улога. Када је реч о чиновима друштвено изазване мржње, резултати су много двосмисленији. Порекло има суштинску улогу у ширењу говора мржње, али ово није случај са распрострањеном (или перципираном) укљученошћу различитих група у насиље. Склоност ка интервенцији и заустављању насиља разликује се према пореклу жртава и починилаца, а неопходно је даље проучавање да би се препознале детерминанте.

Кључне речи: социјална дистанца, антимигрантска осећања, говор мржње, насиље из мржње

\section{Увод}

Могу се разликовати две главне линије теоретисања и анализе у погледу извора антимигрантских осећања, према којима се та осећања могу приписати економској (O’Rourke \& Sinnott, 2006; Dustmann \& Preston, 2007) или културолошкој сукобљености (Davidov \& Meuleman, 2012; Billiet \& De Witte, 1995; Ceobanu \& Escandell, 2008). Већина радова који тврде да су антимигрантска осећања изазвана културолошком сукобљеношћу претпостављају, директно или индиректно, да су симболична забринутост и очекивани социотропски ефекти (Hainmueller \& Hopkins, 2014) повезани са перцепцијама другости миграната у смислу вредности, религије, културе,

\footnotetext{
1 lspasova@bas.bg
} 
етничке припадности, расе итд. (Gorodzeisky \& Semyonov, 2015; Gorodzeisky, 2013; Scheepers, Gijsberts, Coenders, 2002). Међутим, не постоји довољно истраживања о начину на који специфични раскораци између разлика и перципираних облика другости утичу на антимигрантска осећања, а нарочито на ефекте перцепција порекла различитих група на конкретна осећања према њима (неки од значајних изузетака су истраживачи: Blinder \& Markaki, 2018; Heath \& Richards, 2019). Још су peђе студије о утицајима перципираног порекла на антимигрантски говор мржње, злочине из мржње и насиље изазвано мржњом.

Овај рад покушава да попуни ту празнину анализирајући утицаје перципираног порекла миграната на антимигрантска осећања у Бугарској мерена кроз социјално дистанцирање у односу на разне мигрантске групе и кроз испољавање друштвено изазване мржње. Рад такође даје анализу ширења и прихватања антимигрантског говора мржње и насиља изазваног мржњом.

Студија је део ширег истраживања које финансира Бугарски фонд за науку, а заснован је на подацима из низа репрезентативних анкета о ставовима Бугара према мигрантима и избеглицама на врхунцу таласа појачане миграције, као и после њега.

Структура рада је следећа: први део уводи главне теоријске појмове и концепте; након тога, други део представља методологију емпиријске студије; трећи део приказује податке и резултате истраживања; на крају, последњи део завршава се прегледом најважнијих сазнања и одређених напомена о могућим истраживањима у будућности.

\section{Теоријски оквир}

Постоји велики број студија усредсређених на изворе и последице антимигрантских осећања, али су оне ретко свеобухватне (Ceobanu \& Escandell, 2010; Gorodzeisky, 2013). Разликују се две главне линије теоретисања и анализе које се веома ретко и тек у новије време преклапају (Hainmueller \& Hopkins, 2014; Gorodzeisky, 2013). Прва линија испитивања заснована је на политичкој економији и бави се економским личним интересима или заједничким економским интересима као што су конкуренција на тржишту рада и фискални терет (O’Rourke \& Sinnott, 2006; Dustmann \& Preston, 2007). Друга, социопсихолошка линија, указује на то да се извори антимигрантских ставова могу наћи у перцепцијама социотропског утицаја (Hainmueller \& Hopkins, 2014) на земљу и друштво домаћина. Студије у овој парадигми су много хетерогеније и проучавају мноштво фактора, као што су идентитети и вредности (Davidov \& Meuleman, 2012; Billiet \& De Witte 1995), национализам (Ceobanu \& Escandell, 2008) и перципирана претња (Scheepers et al., 2002). Упркос обимним истраживањима, нема много доказа да су антимигрантски ставови засновани на стварним или очекиваним утицајима на личну економску ситуацију. Најновија истраживања много доследније показују да су ставови према мигрантима „углавном изазвани симболичном забринутошћу за нацију у целини” (Hainmueller \& Hopkins, 2014, стр. 227) или „забринутошћу због услова или карактеристика мигрантске популације” (Markaki, Longhi, 2013, str. 332). 
Дастман и Престон дају доказе да су расне или културолошке предрасуде важна компонента у ставовима према миграцијама, када је реч о миграцији из земаља са етнички различитим становништвом (Dustmann and Preston (2007).

На сличан начин, према Городзејској и Семјонову, антимигрантска осећања, а нарочито искључиви ставови, могу настати на основу националног порекла или националне припадности и на основу расе и етничке припадности. Први тип је „неселективно усмерен на све особе које не припадају једној нацији (или 'странце'), без обзира на њихову расу или етничку припадност”, а други је „усмерен селективно само на неевропске етничке и расне мањине” (Gorodzeisky \& Semyonov, 2009, стр. 416). Ови аутори тврде да су Европљани спремнији да одобре одбацивање миграната који немају европско порекло него миграната са европским пореклом. Городзејски и Семјонов (2015) даље развијају ову тезу, према којој су етничке и расне предрасуде према неевропским/небелачким мањинама и конкурентска претња (како на индивидуалном, тако и на државном нивоу) два независна извора ставова према свим мигрантима, тј. предрасуда служи и као вишак у перцепцији претње и као независни фактор антимигрантских осећања. Штавише, по мишљењу ових аутора, „расне предрасуде према небелачким/неевропским групама треба посматрати као независан (и додатни) извор негативних ставова према мигрантима уопште” (Gorodzeisky \& Semyonov, 2015, str. 20).

Као што Анастазија Городзејски указује у другој линији истраживања (Gorodzeisky, 2011), антимигрантска осећања нису изазвана само етничким или расним предрасудама, већ и перцепцијама услова у земљи порекла. Користећи податке из првог круга Европског социјалног прегледа (ESS) и укрштајући ставове према мигрантима из сиромашнијих насупрот богатијим земљама Европе, ауторка препознаје четири категорије ставова: про-адмисионисте, тоталне ексклузионисте, ексклузионисте сиромашних земаља и ексклузионисте богатих земаља. Городзејски (2011) сматра да су ексклузионистички погледи усмерени искључиво на странце из „сиромашнијих земаља Европе” или на странце „из богатијих земаља Европе” прилично бројни, иако их већина људи не разликује. Исто тако, Блајндер и Маркаки нашли су доказе да како економски услови у земљи порекла, тако и порекло у оквиру или ван ЕУ, могу да имају улогу у ставу према мигрантима (Blinder \& Markaki, 2018). У својим закључцима ова два аутора иду корак даље од Городзејске, тврдећи да су економски услови у земљи порекла много важнији за антимигрантска осећања него европско или неевропско порекло.

У недавно објављеном чланку Хит и Ричардс пружају доказе о значајној стабилности током времена у ставовима према мигрантима и осећањима према разним групама миграната. По њиховом мишљењу, мигранти „из исте расне или етничке групе као већина прихватљивији су од оних из различите етничке групе или из сиромашнијих земаља Европе, који су ипак донекле прихватљивији од оних из сиромашнијих земаља ван Европе" (Неath \& Richards, 2019, str. 17). Ови аутори такође закључују да постоје негативнији ставови према муслиманским мигрантима, док су најнепожељнији мигранти ромског порекла. 
Када је реч о предрасудама против миграната, у ранијим радовима, Петигру (Pettigrew, 1998) тврди да су таласи појачане миграције довели до већих предрасуда, директне и индиректне дискриминације, политичке опозиције и распрострањеног насиља над мигрантима и мигрантским мањинама.

Надовезујући се на претходна сазнања о злочинима из мржње и говору мржње (Spasova, 2019), ова студија претпоставља да су главни фактор за агресију и насиље у односима између група, а нарочито оних које су усмерене на мигранте, управо предрасуде - искривљене категоризације друштвених група. Предрасуде се схватају као „негативна оцена неке друштвене групе или негативна оцена одређеног појединца на основу његове припадности групи” (Crandall \& Eshleman, 2003, str. 414), која се шири путем културе и интернализује путем искуства (нпр. Dunham, Chen, Banaji, 2013).

Чинови мржње - насиље изазвано мржњом, злочини из мржње и говор мржње - су девијантни чинови подстакнути предрасудама, који служе да се додатно потврде предрасуде групе са којом се починиоци идентификују. Према Олпортовом класичном схватању, мржња се овде односи на комплексну менталну појаву која представља „перманентну организацију агресивних импулса према особи или групи људи”, то јест тешку структуру у менталном и емоционалном животу појединца (Allport, 1979, str. 363). У том смислу, мржња је временски стабилна - осећање, а не емоција или афект, и мање-више пасиван, али покретачки импулс повезан са понашањем. Мржња је оно што делује као „покретачка сила насиља” (Kressel, 2002).

Важно је истаћи да мржња не мора да буде главни мотив за криминални или насилни чин како би се тај чин класификовао као испољавање друштвено изазване мржње. Као што наглашавају други истраживачи (McDevitt, Levin, Bennett, 2002); Perry, 2009; Walters, 2011), чак и када мржња није главни мотив за одређени криминални чин, она и даље може да има значајну улогу у целокупној мотивацији, на пример у одабиру жртве. Слична томе је разлика коју су описали Херек, Берил и Берил (Herek, Berrill \& Berrill, 1992) између „експресивних” и „евалуативних” напада изазваних мржњом: експресивно насиље има за циљ да уништи или повреди жртву због њеног идентитета и припадности одређеној групи, док је евалуативно насиље усмерено на конкретну жртву због њене перцепције као очигледног циља.

Иако говор мржње није обавезно сам по себи насилан, одређени број студија недвосмислено повезује употребу говора мржње са покретањем насиља (нпр. Yanagizawa-Drott, 2014; Benesh, 2012). Овај термин обухвата подстрек на насиље, радикализам и геноцид, што према закону представља злочин, као и вређање и квалификације засноване на идентификацији са и припадности одређеној групи која сама по себи није криминализована. У студији се користи дефиниција говора мржње према којој су ово „облици изражавања који шире, подстичу, омогућавају или оправдају наношење штете (а поготово дискриминацију, непријатељство или насиље) на основу друштвене или демографске припадности жртве некој групи” (UNESCO, 2015).

За разумевање утицаја говора мржње пресудне су студије такозваног „опасног говора” (Benesh, 2012) и „језика страха” (Buyse, 2014), које наглашавају учесталост говора мржње и бројност оних који тај говор користе - без обзира на то да ли је реч 
о функционерима, новинарима или обичним грађанима. Према истраживању медијског садржаја који претходи чиновима геноцида, употреба говора мржње међу функционерима или у званичним медијима је кључ за објективизацију мржње и радикализма у насиље (Benesh, 2012; Leader Maynard\&Benesch, 2016).

\section{Методологија истраживања}

Емпиријски подаци сакупљају се путем низа интервјуа лицем у лице (енгл. PAPI) са структурисаним упитником. Информације које се користе у анализи углавном потичу из последњег истраживања које је спроведено у септембру и октобру 2019, као што је већ поменуто - после смањења масовног прилива миграната из земаља које нису чланице ЕУ. Поређења ради, у анализи се у неколико наврата користе подаци из таласа миграната у периоду новембар-децембар 2017. године. Узимајући у обзир значај просторне и психолошке близине и удаљености (Liberman \& Chaiken, 1996), обе студије замишљене су као двостепени угнежђени узорак и примењују модел узорка који је национално репрезентативан за одрасло становништво. Узорци су насумично стратификовани и обухватају 840 особа 2019. и 800 особа 2017. године. Стратификација је урађена према NUTS 2 на основу величине насеља. Насеља су подељена у шест група, а узорак не обухвата насеља са мање од стотину људи (односно 1\% укупног становништва). Има 80 гнезда са по десет обављених интервјуа. Извор информација за узорковање у обе студије је попис становништва из 2011. године - подела према старосним групама за свако насеље. Процењује се да стохастичка грешка на $50 \%$ износи $\pm 3,5 \%$. Подаци се пондеришу према полу и годинама старости.

У циљу проучавања антимигрантских осећања, студија примењује прилагођену варијанту Богардусове скале социјалне дистанце (Bogardus, 1959). Инспирисан Зимеловим идејама о геометрији друштвеног живота (Wark \& Galliher, 2007), Богардус је смислио скалу за мерење предрасуда и за „смањење рационализовања... у највећој могућој мери" (1959, str. 30). Првобитна скала је изузетно једноставна и састоји се од седам улога са растућим нивоом социјалне близине и ближег контакта. Од испитаника се тражи да одаберу најближи степен интимности који сматрају одговарајућим за представнике одређених етничких група. У овој студији користе се четири степена близине на Богардусовој скали социјалне дистанце - први сусед, непосредни надређени или послодавац, супружник блиског рођака и близак пријатељ. Скала социјалне дистанце модификована је помоћу скале сличне Ликертовој, са четири категорије одговора за сваку засебну улогу, чиме се кумулативна Богардусова скала претвара у низ засебних питања са једнодимензионалном скалом.

Начини испољавања друштвено изазване мржње - говор мржње и насиље из мржње - проучавају се на основу питања о искуству, мишљењу и батерије оригиналних пројективних питања, специјално припремљених за ово истраживање. Пројективна питања имају за циљ да укажу на одговоре описујући наводно понашање испитаника у разним ситуацијама насиља повезаног са мигрантима/странцима, дефинисаног само на основу порекла жртава и нападача. 


\section{Резултати}

Када је реч о социјалној дистанци и прихватању, упркос малим варијацијама, мигранти различитог порекла могу се поделити у два кластера са сличним резултатима у оквиру кластера и знатном разликом између њих. Први кластер обухвата мигранте који су више и лакше прихваћени, те се могу назвати „блиским мигрантима”. То су мигранти етничког бугарског порекла, али рођени и одгајени ван Бугарске, као и остали Европљани из земаља ЕУ и ван ње. Други кластер обухвата мигранте који су мање прихваћени, нарочито услед повећане социјалне удаљености, и могу се назвати „далеким мигрантима”. У овом кластеру су мигранти из Африке, са Блиског истока (Сирија, Ирак, Авганистан итд.) и из Кине [Графикон 1].

Приближно трећина Бугара би се осећала потпуно лагодно уколико би њихов први сусед био неко из групе „блиских миграната” - Европљанин из земље ван ЕУ (34\%) или етнички Бугарин из неке друге земље (31\%), док би једна трећина осећала одређени степен нелагодности (32\%, односно 33\%). Када је реч о мигрантима из Африке и са Блиског истока, отприлике две трећине кажу како би се осећали нелагодно ( $31 \%$ „потпуно нелагодно”, 31\% „донекле нелагодно” због особе са Блиског истока, а $34 \%$ „потпуно нелагодно” и 29\% „донекле нелагодно” због особе из Африке). Свега 9\% односно 8\% Бугара осећало би се потпуно лагодно уколико би њихов сусед био из Африке, односно са Блиског истока.

Када је реч о непосредном надређеном или послодавцу, 25\% Бугара изјављује да би им било потпуно прихватљиво да је на том положају неки Европљанин ван ЕУ или етнички Бугарин из неке друге земље, док $36 \%$ каже да би се осећали нелагодно (16\% - „потпуно нелагодно”, 20\% „донекле нелагодно” због етничког Бугарина; $15 \%$ „потпуно нелагодно” и $21 \%$ „донекле нелагодно” због Европљанина ван ЕУ). Знатно је нижи степен прихватања остале три групе на другим положајима. Бугари би се осећали најмање лагодно уколико би њихов непосредни надређени био са Блиског истока - у тој хипотетичкој ситуацији потпуно лагодно би се осећало свега $10 \%$, донекле нелагодно - 24\% и потпуно нелагодно - 31\% Бугара.

Дистрибуција преферентне социјалне дистанце према различитим групама миграната када је реч о особи која је супружник блиског рођака указује на још упадљивије разлике између два кластера испитаника, а готово идентичне резултате за групе унутар сваког од њих. Укупно 29\% Бугара осећало би се потпуно лагодно уколико би у њихову породицу путем женидбе/удаје дошла особа из групе блиских миграната, док би се свега 7\% њих (или 6\% када је реч о Африканцима) тако осећало у истој ситуацији, али када је реч о некоме из групе далеких миграната. Иако са минималном разликом, људи из Африке су најмање пожељни - $20 \%$ испитаника изјавило је да им нечије порекло није важно, 6\% би се осећало потпуно лагодно, 23\% - донекле нелагодно, а 50\% - потпуно нелагодно.

Важно је напоменути да за све нивое близине постоје разлике у погледу исказаног значаја порекла. На пример, када је реч о доласку неке особе у породицу путем женидбе/удаје, где је раскорак највећи, $31 \%$ испитаника је то изјавило за мигранте европског порекла, 29\% - за етничке Бугаре из неке друге земље, $22 \%$ за мигранте са Блиског истока, а 20\% за мигранте из Африке. Овакав раскорак не би требало да постоји да је, као што одговор сугерише, порекло рођака који улазе у породицу путем 
женидбе/удаје у стварности небитно. Могуће објашњење било би постојање одређеног степена друштвене пожељности у овим одговорима, што, међутим, не функционише довољно добро када је реч о „далеким” мигрантима.

Индекс социјалне дистанце који одражава ниво лагодности замишљен је тако да би се омогућило поређење које обухвата како посматране групе миграната, тако и посматране друштвене улоге. Овај индекс направљен је на основу значаја додељеног разним нивоима лагодности и користи вредности између 0 и 100. где 0 означава потпуну нелагодност за све, а 100 - потпуну лагодност, где је порекло небитно за све. Овај индекс открива неколико прилично занимљивих резултата. Донекле је изненађујуће видети да су за горе наведене улоге етнички Бугари мање пожељни од осталих Европљана. Међутим, као што ће се видети у анализи која следи, ово није случај када је реч о блиским пријатељима. Осим тога, за групу блиских миграната, најприхватљивија је улога првог суседа, док је за групу далеких миграната најприхватљивија улога непосредног послодавца. Ова разлика је још један значајан раскорак у груписању миграната као блиских и далеких.

Када је реч о следећој тестираној улози - улози блиског пријатеља, Бугарима су најприхватљивији етнички Бугари који живе у некој другој земљи, при чему је $78 \%$ испитаника спремно да их прихвати. На другом месту су Европљани из земаља ван ЕУ, где је 71\% испитаника спремно да их прихвати. Мигранти са Блиског истока, из Африке и Кине су много мање прихватљиви, као што је и очекивано. Особу из Кине би као блиског пријатеља прихватило 44\%, особу са Блиског истока - 38\%, а особу из Африке - 35\% испитаника.

Иако је индекс социјалне дистанце за ову улогу прилично висок, нарочито за кластер далеких миграната, поређење са подацима из 2017. показује могући пораст у нивоу прихватања. Треба имати на уму методолошка разматрања која се односе на чињеницу да 2017. прихватање није тестирано за различите групе, већ уопштено за све мигранте. Подаци показују да би 2017. године - која је временски била много ближе врхунцу прилива миграната - свега 23\% Бугара прихватило мигранта, без обзира на његово порекло, као свог блиског пријатеља. Године 2019. стопа прихватања је неколико пута виша за блиске мигранте, а много виша чак и за далеке мигранте. Могуће објашњење за ове резултате јесте смањена осетљивост на ову тему услед смањеног прилива миграната, што је, према неким тврдњама, повезано са смањеном перцепцијом могуће претње и ублажавањем социјалне фобије.

Поред тога, резултати процењене распрострањености говора мржње пружају веома занимљива запажања.

Према испитаницима, изјаве које садрже увредљиве квалификације најчешће су усмерене против миграната из Африке и са Блиског истока (при чему је испитаницима дата слобода да самостално закључе шта се квалификује као увредљива изјава). Њих $21 \%$ каже да често чују такве изјаве, $40 \%$ их чују прилично ретко, а $39 \%$ - никада. На следећем месту по распрострањености су такве изјаве против миграната из Кине, а следе изјаве против миграната бугарског порекла из других земаља и изјаве против држављана других европских земаља. Испитаници најређе чују увредљиве изјаве о мигрантима из европских земаља ван Европске уније -5\% такве изјаве чује често, $30 \%$ - прилично ретко, а $65 \%$ - никада. 
Веома је слична, али са много нижим вредностима, распоређеност озбиљнијих врста говора мржње - оних који садрже претње и агресију (и овде је испитаницима дата слобода да сами закључе шта се квалификује као претња и вербална агресија). На основу резултата, такве изјаве против миграната из Африке и са Блиског истока поново су најчешће, али овде је њих 9\% чуло такве изјаве, $27 \%$ их је ретко чуло, а $64 \%$ - никада. Најређе су увредљиве изјаве, изјаве које садрже претње и агресију против миграната из европских земаља ван ЕУ - такве изјаве чуло је 3 \% испитаника, 19\% - веома ретко, а 78\% - никада.

Да би се омогућило истовремено поређење оба типа изјава пуних мржње према свим групама миграната, направљен је индекс говора мржње тако што се као значајне узимају три варијабле на скали за оцену распоређености. Овај индекс користи вредности између 0 и 100, где 0 значи да нико никада није чуо такве изјаве, док 100 значи да сви овакве изјаве оцењују као прилично уобичајене Графикон 2 .

Као што се види на основу овог индекса, разлика између распоређености изјава које садрже увредљиве квалификације и оних које садрже претње и агресију је у нивоу, а не у пропорцијама. Ово се односи и на сразмере унутар сваке групе миграната и на односе између разних група. Слична распоређеност указује на претпоставку да постоји однос између две групе изјава, а ту претпоставку поткрепљује и анализа корелација. Резултати показују постојање статистички значајне повезаности између оцена испитаника о степену распрострањености два типа изјава, са највећим вредностима када се оба типа изјава односе на исту групу миграната. На пример, за мигранте из европских земаља ван ЕУ, који су, по мишљењу испитаника, у најмањем степену предмет како увредљивих изјава, тако и изјава са претњама и агресијом, корелационе вредности су: апроксиматни значај $=0,000$; Крамеров В-коефицијент $=0,541$. За мигранте из Африке и са Блиског истока, који су најчешће изложени обема врстама изјава мржње, ове вредности су: апроксиматни значај $=0,000$; Крамеров В-коефицијент $=0,487$.

Када је реч о опасном говору - говору мржње јавних личности против миграната и избеглица - према подацима ове анкете, 11\% Бугара одобрава увредљиве фразе које користе политичари, 10\% - фразе новинара, њих 22\% сматра прихватљивом употребу говора мржње међу обичним људима, а 15\% одобрава сопствену употребу тог говора (Графикон 3). Када је реч о сразмери, ова распоређеност одговара резултатима из 2017, иако је од тада дошло до значајног пада у целокупном нивоу прихватања. Године 2017, на идентично питање 19,2\% испитаника навело је да прихватају употребу говора мржње и увредљивих фраза међу политичарима, $20,1 \%$ - међу новинарима, 44,1\% - међу обичним људима, а 35,6\% - сопствену употребу тих фраза.

Иако овај узорак не дозвољава запажања и закључке на нивоу виктимизације злочина из мржње или злочина из мржње којима се повређују мигранти, одређене информације могу се добити из резултата на основу искуства очевидаца агресивног понашања и чинова насиља. Релативно мали број испитаника пријавио је да су били сведоци агресивног понашања од стране или против странаца и миграната, при чему су агресивни чинови које су починили мигранти углавном ређи него они 
против њих. Седам посто испитаника били су сведоци агресивног понашања грађана из других земаља ЕУ, миграната из европских земаља ван ЕУ и миграната са Блиског истока и из Африке, а 4\% - агресивног понашања миграната из Азије. Примере агресивног понашања усмереног против држављана осталих земаља ЕУ видело је $12 \%$ испитаника. Њих $8 \%$ изјавило је да је видело агресију усмерену против миграната са Блиског истока и из Африке, 7\% - против миграната из европских земаља ван ЕУ, а 5\% - против миграната из Азије.

Резултати добијени на основу пројективних питања показују да су прихватање и одобравање антимигрантског насиља много већи од броја пријављених насилних инцидената. У замишљеној ситуацији насиља против миграната, при чему треба нагласити да се жртва дефинише само на овој основи, 80\% испитаника слаже се да насиље никада није оправдано, али њих $20 \%$ је за опцију да су „мигранти криви требало је да остану тамо одакле су”. Подаци недвосмислено показују висок ниво нормализације чинова физичког насиља и злочина из мржње, као и то да су резултати из 2017. потпуно исти, тј. овакав став је стабилан већ дуго времена.

Низ пројективних питања о претпостављеним реакцијама испитаника у насилним ситуацијама такође показује снажан утицај предрасуда против припадника других група. Иако није испитана конкретна ситуација са мигрантима, резултати су важни за разумевање ставова према разним групама миграната. Уопштено узев у насилној ситуацији која није дефинисана на посебан начин, 13\% Бугара оцењује као веома велику вероватноћу интервенисања ради спречавања насиља, 32\% њих би вероватно интервенисало у одређеној мери, 29\% - у малој мери, док 27\% њих уопште не би интервенисало. У ситуацијама када су жртве бугарског порекла, а починиоци припадају разним другим групама, вероватноћа и спремност на интервенцију ради спречавања насиља је слична (у оквиру маргине грешке) оној у уопштеној ситуацији. Иако са малом разликом, занимљиво је поменути да је, у случају када су нападачи из неке друге етничке групе и у случају када су нападачи друге расе, забележен већи проценат људи који мисле да би највероватније реаговали. Када су нападачи из друге етничке групе, 14\% испитаника оцењују вероватноћу интервенције као веома велику, а 28\% њих као непостојећу, док је у случају када је нападач друге расе, $15 \%$ испитаника оценило вероватноћу интервенције као веома велику, а $27 \%$ њих као непостојећу. У ситуацијама када су позиције обрнуте, односно када су Бугари починиоци, а припадници неких других група жртве, спремност на интервенцију мања је него у уопштеној ситуацији. На пример, у ситуацији када су жртве друге расе или етничке припадности, $8 \%$ испитаника би највероватније интервенисало у великој мери, док $31 \%$ њих уопште не би реаговало. У случају жртава друге вере, ови проценти су $8 \%$, односно $32 \%$, а у случају жртава страног порекла, $7 \%$, односно $32 \%$.

Разлике у ставу и вероватноћи реаговања у разним ситуацијама јасно се виде на индексном графикону на којем је значај додељен различитим степенима вероватноће (Графикон 4. Индекс користи вредности између 0 и 100, где 0 значи да нико неће реаговати и интервенисати, а 100 значи да вероватноћу интервенције сви оцењују као веома велику. 


\section{Дискусија и закључак}

Ова студија показује да перципирано порекло има значајан утицај на антимигрантска осећања у Бугарској, како у погледу социјалне дистанце према разним мигрантским групама, тако и у погледу испољавања и прихватања чинова друштвено изазване мржње.

Када је реч о социјалној дистанци и прихватању миграната, постоје два кластера - „далеки” и „блиски”, а разлика између њих није само у нивоима прихватања, већ и у различитом рангирању улога у складу са преференцијама у прихватању. Разлика у рангирању улога указује на то да улоге нису обавезно моновалентне у смислу социјалне дистанце и то је важан показатељ за категоризацију мигрантских група у ова два кластера.

Иако начелно изгледа да су мигранти у „далеком” кластеру по правилу из земаља које су удаљеније у смислу географије или културе, док они у „блиском” кластеру долазе из земаља које су физички ближе, социјална дистанца није директан одраз географске или културолошке удаљености. На пример, резултати сведоче о томе да су људи из Кине углавном прихваћенији од људи са Блиског истока у готово свим друштвеним улогама, иако су људи са Блиског истока ближи како културолошки, тако и географски. Осим тога, насупрот очекивањима, етнички Бугари који живе у некој другој земљи, а који су наводно најближи у погледу културе, нису најприхваћенија група за три од четири тестиране улоге. Неопходно је даље истраживање како би се повећало разумевање ових резултата и пружила могућа објашњења.

Када је реч о распрострањености и прихватању чинова мотивисаних друштвено изазваном мржњом, перципирано порекло миграната има огроман утицај иако су резултати много двосмисленији. Распрострањеност говора мржње варира у погледу миграната различитог порекла, па се не могу направити кластери група. Распрострањеност и прихватање говора мржње не показују опасне трендове као што је то случај са прихватањем изјава које садрже агресију и претње, на нижем су нивоу од прихватања увредљивих изјава, док је опасни говор мање прихваћен говор мржње који користе обични људи.

Релативно мали удео испитаника изјавио је да су били сведоци чинова насиља у којима су били укључени мигранти или странци - било као жртве или починиоци. Упркос томе, резултати показују да се углавном мигранти и странци чешће посматрају као жртве, а не починиоци насиља. Ни овде нема основа за прављење кластера различитих група у вези са укљученошћу у насиље.

Постоје разлике у спремности на интервенцију и спречавање насиља у зависности од улога и порекла жртава и починилаца. Међутим, спремност на реаговање у различитим ситуацијама веома је чврсто повезана са спремношћу на реаговање уопште, па је неопходна нова студија која би препознала најснажније детерминанте.

Поређења са подацима из претходних година откривају извесне противречности. Док је забележен упадљив пад антимигрантских осећања кад је реч о социјалној дистанци и одобравању антимигрантског говора мржње, одобравање антимигрантских чинова насиља и даље се задржало на истом нивоу. У наредним годинама неопходна су даља истраживања како би се испитало да ли су ти резултати случајна варијација, пролазна појава или тренд, односно - промена у антимигрантским осећањима. 


\section{REFERENCES / ЛИTЕРATУPA:}

Allport, G. B. [1954] (1979). The nature of prejudice, Reading, MA: Addison-Wesley. Benesch, S. (2012). Dangerous Speech: A Proposal to Prevent Group Violence, http://www. worldpolicy.org/sites/default/files/Dangerous\%20Speech\%20Guidelines \%20Benesch\%20)anuary\%202012.pdf(20.07.2018)

Billiet, J., De Witte, H. (1995). Attitudinal dispositions to vote for a 'new' extreme rightwing party: The case of 'Vlaams Blok'. European Journal of Political Research, 27(2), 181-202.

Blinder, S., Markaki, Y. (2018). Europeans' Attitudes to Immigration from Within and Outside Europe: A Role for Perceived Welfare Impacts? Working Paper: D10, 1. Retrieved from www.reminder-project.eu

Bogardus, E. (1959). Social distance. Yellow Springs, OH: Antioch Press

Buyse, A. (2014). Words of Violence: "Fear Speech," or How Violent Conflict Escalation Relates to the Freedom of Expression. Human Rights Quarterly, 36(4), 779-797.

Ceobanu, A. M., Escandell, X. (2008). East is West? National feelings and anti-immigrant sentiment in Europe. Social Science Research, 37(4), 1147-1170.

Ceobanu, A. M., Escandell, X. (2010). Comparative analyses of public attitudes toward immigrants and immigration using multinational survey data: A review of theories and research. Annual review of sociology, 36, 309-328.

Crandall, C. S., Eshleman, A. (2003). A justification-suppression model of the expression and experience of prejudice. Psychological bulletin, 129(3), 414.

Davidov, E., Meuleman, B. (2012). Explaining attitudes towards immigration policies in European countries: The role of human values. Journal of Ethnic and Migration Studies, 38(5), 757-775.

Dunham, Y., Chen, E. E., Banaji, M. R. (2013). Two Signatures of Implicit Intergroup Attitudes. Psychological Science, 24(6), 860-868.

Dustmann, C., Preston, I. P. (2007). Racial and Economic Factors in Attitudes to Immigration. The B. E. Journal of Economic Analysis \& Policy, 7(1). doi:10.2202/1935-1682.1655

Gorodzeisky, A. (2011). Who are the Europeans that Europeans prefer? Economic conditions and exclusionary views toward European immigrants. International Journal of Comparative Sociology, 52(1-2), 100-113.

Gorodzeisky, A. (2013). Mechanisms of exclusion: attitudes toward allocation of social rights to out-group population. Ethnic and Racial Studies, 36(5), 795-817.

Gorodzeisky, A., Semyonov, M. (2009). Terms of exclusion: public views towards admission and allocation of rights to immigrants in European countries. Ethnic and Racial Studies, 32(3), 401-423. doi:10.1080/01419870802245851

Gorodzeisky, A., Semyonov, M. (2015). Not only Competitive Threat but also Racial Prejudice: Sources of Anti-Immigrant Attitudes in European Societies. International Journal of Public Opinion Research, 28(3), 331-354.

Hainmueller, J., Hopkins, D. J. (2014). Public attitudes toward immigration. Annual Review of Political Science, 17.

Heath, A., Richards, L. (2019). How do Europeans differ in their attitudes to immigration? Findings from the European Social Survey 2002/03-2016/17. 
Herek, G. M., Berrill, K. T., Berrill, K. (1992). Hate crimes: Confronting violence against lesbians and gay men. Sage.

Kressel, N. (2002). Mass Hate: The Global Rise of Genocide and Terror (Revised and Updated). Plenum Press: New York

Leader Maynard, J., Benesch, S. (2016). Dangerous Speech and Dangerous Ideology: An Integrated Model for Monitoring and Prevention. Genocide Studies and Prevention: An International Journal: Vol. 9: Iss. 3: 70-95.

Liberman, A., Chaiken, S. (1996). The direct effect of personal relevance on attitudes. Personality and Social Psychology Bulletin, 22(3), 269-279.

Markaki, Y., \& Longhi, S. (2013). What determines attitudes to immigration in European countries? An analysis at the regional level. Migration Studies, 1(3), 311-337. doi:10.1093/migration/mnt015

McDevitt, J., J. Levin, S. Bennett. (2002). Hate Crimes Offenders: An Expanded Typology. Journal of Social Issues, 58 (2): 303-317

O'Rourke, K. H., Sinnott, R. (2006). The determinants of individual attitudes towards immigration. European Journal of Political Economy, 22(4), 838-861.

Perry, B. (2009). The Sociology of Hate: Theoretical Approaches. In: Levin, B. (ed.) Hate Crimes: Understanding and Defining Hate Crime. Westport, CT: Praeger, 54-77

Pettigrew, T. F. (1998). Reactions Toward the New Minorities of Western Europe. Annual Review of Sociology, 24(1), 77-103. doi:10.1146/annurev.soc.24.1.77

Scheepers, P., Gijsberts, M., Coenders, M. (2002). Ethnic exclusionism in European countries. Public opposition to civil rights for legal migrants as a response to perceived ethnic threat. European sociological review, 18(1), 17-34.

Spasova, L. (2019). Hate crime. Mechanisms for normalization of socially induced hatred. Sofia, Avangard Prima. ISBN 978-619-239-160-7, 313 [in Bulgarian]

Walters, M. A. (2011). A General Theories of Hate Crime? Strain, Doing Difference and Self Control. Critical Criminology, 19(4), 313-330

Wark, C., \& Galliher, J. F. (2007). Emory Bogardus and the Origins of the Social Distance Scale. The American Sociologist, 38(4), 383-395.

Yanagizawa-Drott, D. (2014). Propaganda and conflict: Evidence from the Rwandan genocide. The Quarterly Journal of Economics, 129(4), 1947-1994.a 


\section{APPENDIX / ПРИЛОГ}

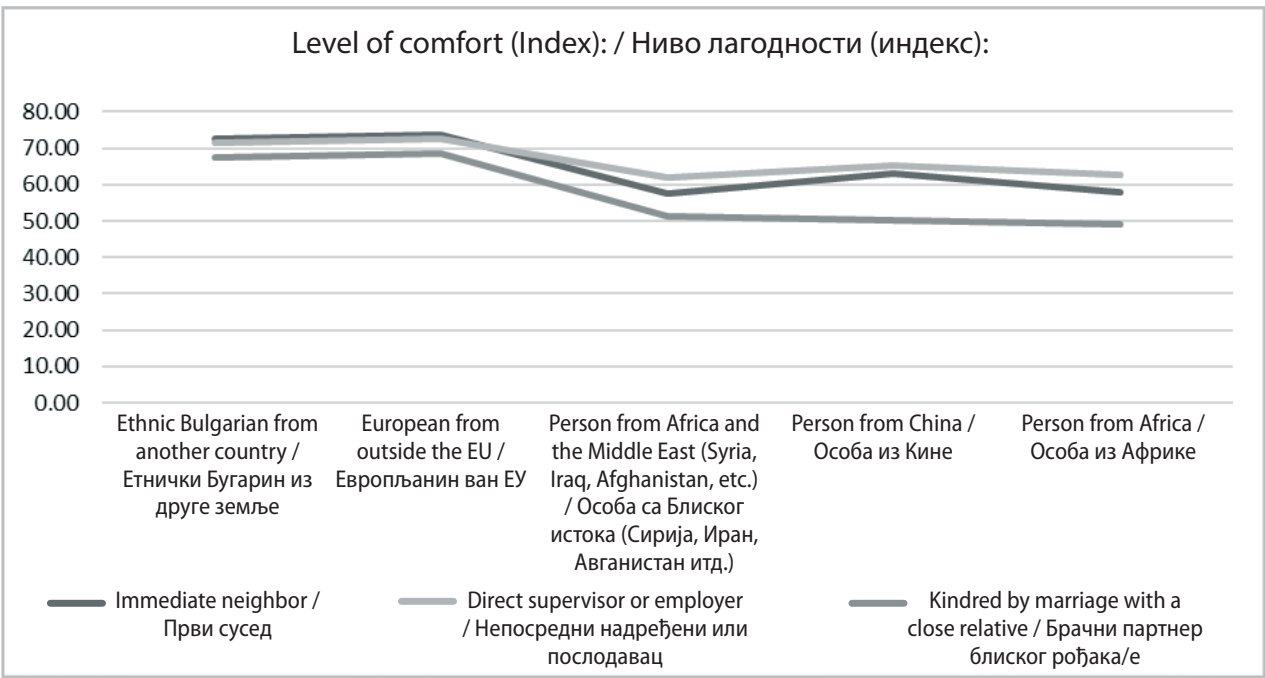

Figure 1. Social distance index (100 - complete acceptance by all, 0 - complete estrangement by all) /

Графикон 1. Индекс социјалне дистанце (100 - потпуно прихватање од свих, 0 - потпуно одбацивање од свих)

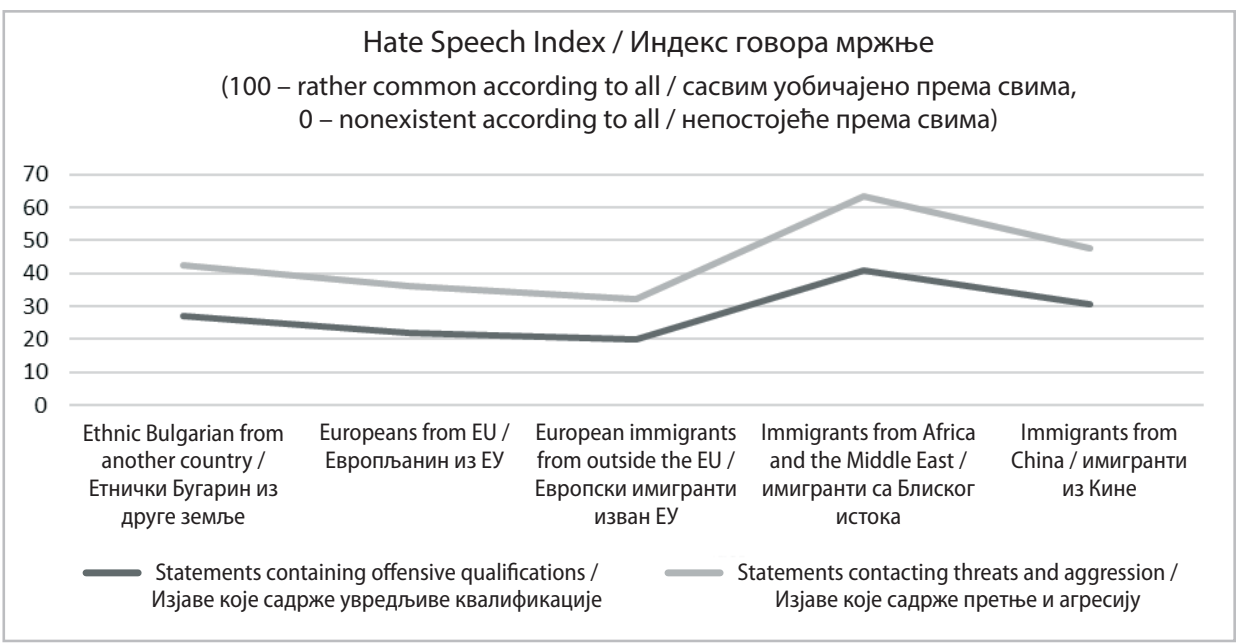

Figure 2. Spread of anti-immigrant hate speech according to origin (index) / Графикон 2. Ширење антимигрантског говора мржње према пореклу (индекс) 


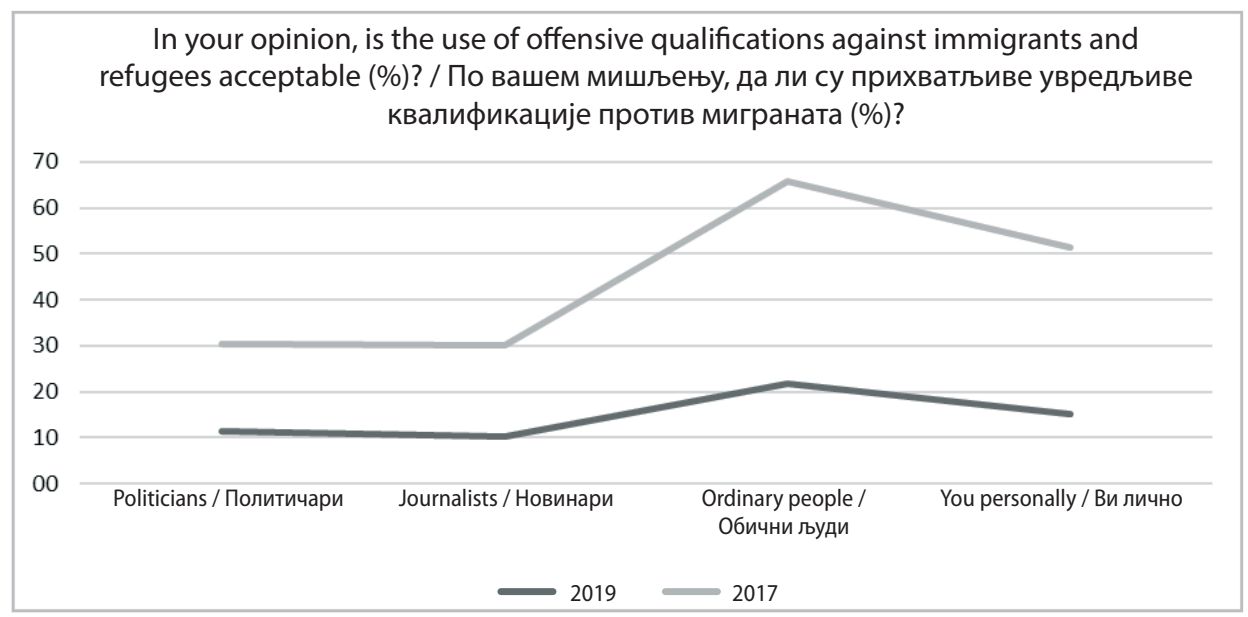

Figure 3. Hate speech and dangerous speech acceptance /

Графикон 3. Прихватање говора мржње и опасног говора

How likely are you to intervene in a situation of violence and prevent it if (Index; "Not at all" = 0, "To a very large extent" $=100$ ) / У којој мери је вероватно да ћете интервенисати у насилној ситуацији и спречити је (Индекс: „Уопште не“ $=0$, „У веома великој мери“ $=100)$

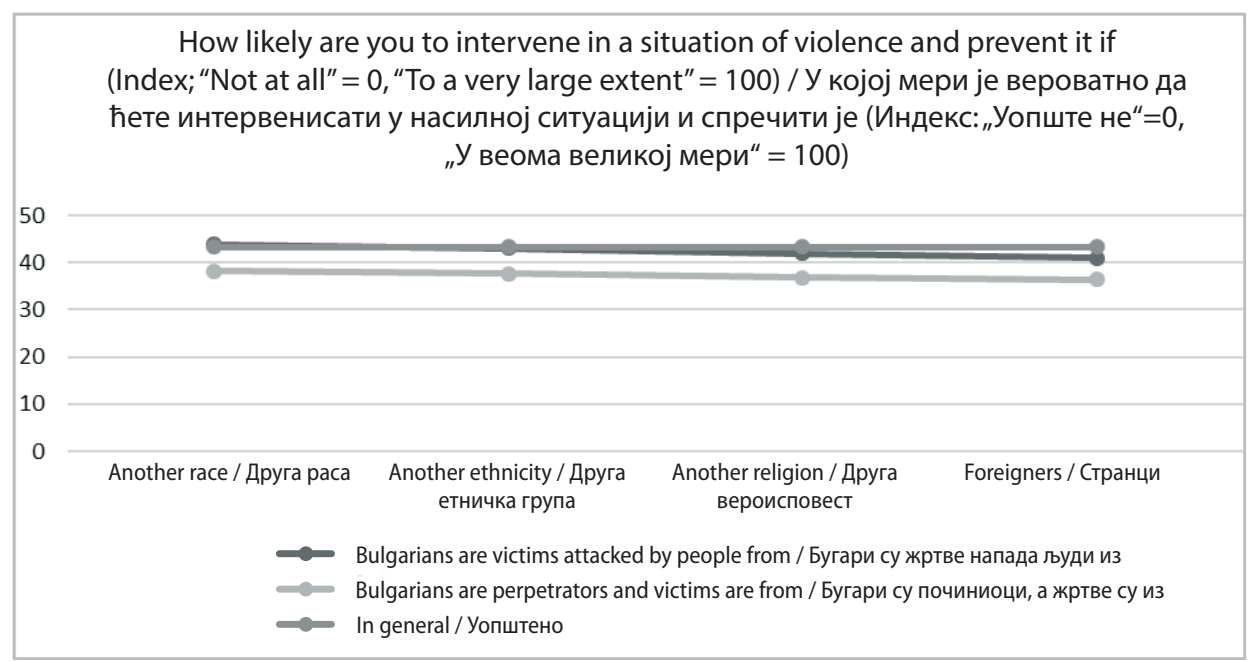

Figure 4. Hate speech and dangerous speech acceptance / Графикон 4. Прихватање говора мржње и опасног говора 